in the process of teaching the block of information disciplines // Modern problems of science and education. - 2015. - № 5 URL: http://www.scienceeducation.ru/ru/article/view?id=22282 (date accessed: 02/07/2021).

2. Pometun O. Interactive learning technologies: theory, practice, experience / O. Pometun, L. Pirozhenko. - Kyiv, 2002. - 98 p.

3. Traditions and innovations in methods of teaching foreign languages: [textbook. way. for students. and teaches.] / [ed. M.K. Kolkovoy]. 2007. $-267 \mathrm{c}$.

DOI https://doi.org/10.30525/978-9934-26-039-1-94

\title{
ДИСТАНЦІЙНЕ ВИВЧЕННЯ ІНОЗЕМНОЇ МОВИ ДЛЯ РОЗВИТКУ КРИТИЧНОГО МИСЛЕННЯ СТУДЕНТІВ
}

\author{
Колосова Г. А. \\ кандидат філологічних наук, \\ доиент кафедри англійської мови гуманітарного спрямування № 3 \\ Національний технічний університет Украйни \\ «Київський політехнічний інститут імені Ігоря Сікорського» \\ м. Київ, Украӥна
}

Проблема «мислення» в різноманітних психолого-педагогічних аспектах є актуальним питанням для вітчизняних і зарубіжних науковців. Важливість та недостатня розробленість цього питання надихнули дослідників до наукового обгрунтування та експериментального впровадження інноваційних методів розвитку критичного мислення студентів вищих навчальних закладів (далі ВН3) на заняттях 3 іноземної мови. Коли людина мислить критично, вона оцінює результати своїх розумових процесів - наскільки правильно ухвалене нею рішення або наскільки вдало вона впорались із поставленим завданням [1, с. 34]. Автономія отримання та практичне застосування знань за допомогою дистанційного навчання стали вагомими проблемами для сучасного студента. Адже, студентська молодь проявляє бажання розпоряджатися можливістю розвивати критичне мислення протягом життя в умовах інформатизованого суспільства.

Питаннями розвитку критичного мислення у студентів займались такі науковці як Andrade D. F., Collin K., Dewey J., Drasgow F., Facione P. A., Harré R., Huitt W., Hulin C. L., Lave J., Wenger E., Paloniemi S., Pasquali L., 
Roberts J. S., Tavares H. R., Valle R. C. та інші. Сучасні методики навчання у вищій школі та дистанційне навчання розглядаються в роботах Aarup J., Agger A., Biggs J., Iversen A.-M., Krogh L., Lundvall B. A., Moravec J. W., Ramsden P., Ramussen P., Schramer O., Stacey R. D., Tortzen A. та інші.

Одним з варіантів допомоги у розвитку критичного мислення може стати дистанційне навчання. Адже, воно створює віртуальну свободу, або іншими словами надає вибір. I чи ввімкнеться тригер «правильного» вибору, або ж ні, залежить від того, хто навчається. Так звана автономія, запропонована в дистанційному навчанні, породжує одну 3 найбільших проблем, а саме уникнення ухилення від віртуального навчального середовища та моменту віч-на-віч. Таким чином, ця автономія, делегована студенту, є сильним фактором впливу на уникнення дистанційних курсів, якщо студент не підготовлений і не усвідомлює свою автономію [4, с. 15].

Безпосередня участь студента через особисту роботу віч-на-віч у віртуальному режимі зміцнює стосунки: викладач-студент, студентстудент, студент-зміст навчання, де знання поєднуються за допомогою особистої та віртуальної діяльності, що, в будь-якому випадку має позитивний результат.

Крім того, використання різних онлайн-посередників, таких як платформи, блоги, вікі, форуми, Facebook, Second life, Twitter, вимагає нових навичок для дистанційного навчання, володіння новими технологіями, новими знаннями та новою поведінкою [3, с. 78]. В нагоді стає володіння іноземною мовою, яке допомагає краще орієнтуватися в сучасних онлайн платформах та розширює можливості студентів щодо використання іншомовних ресурсів.

Дистанційна освіта, як спосіб навчання та розвитку критичного мислення, завдяки своїй простоті та гнучкості, допомагає студентам легко самоорганізуватись. Проте функціональність та популяризація використання комп’ютерів та вдосконалення Інтернету, який стає все більш доступним, призводить до питання - чи насправді всі студенти всіх ВНЗ готові до такого нового типу освіти [2, с. 886].

Використання комп'ютерів полегшило доступ для навчання, і разом 3 цим дистанційна освіта стала дуже популярною серед людей, які відчувають труднощі з пересуванням, сприяючи зменшенню витрат, а також браку часу для відвідування занять в аудиторії. Крім того, така освіта звужує кордони, а географічні відстані вже не є перешкодою для отримання знань у навчальному закладі [3, с. 78$]$. 
Дистанційна освіта $є$ систематизованою формою самостійного навчання, де студент отримує вказівки з представленого йому навчального матеріалу, відслідковує його, а контроль за успіхом студентів здійснює група викладачів. Це можливо завдяки використанню засобів зв'язку, здатних долати великі відстані.

На заняттях з іноземної мови в режимі дистанційної освіти виникає певний ряд обмежень 3 виконання вправ. Наприклад, неможливими стають словникові диктанти або синхронний переклад. Також, ускладняється форма контролю знань студентів: не має можливості заборонити студентам користуватись словниками та онлайн перекладачами підчас виконання контрольних завдань. Тепер викладачу потрібно більше часу витрачати на створення онлайн тестів. 3 іншого боку, практичні заняття в дистанційному режимі розширяють певні можливості як студентів так і викладачів, а саме:

1) Не потрібно перевіряти тестові завдання «вручну». Існує ряд програм, що дозволяють створювати тести, а програма перевіряє їх автоматично.

2) Безмежність можливостей перегляду відео та прослухування аудіо в інтернеті з теми заняття 3 подальшим їх обговоренням іноземною мовою.

3) Відсутність паперової роботи та накопичення «макулатури» -всі матеріали здаються студентами в електронній формі.

4) Зниження впливу «людського фактору». Це стосується як перебування студентами в одній аудиторії (коли вони можуть відчувати незручність від публічних виступів), так і питання пунктуальності (в онлайн режимі запізнитись на заняття через проблеми 3 транспортом неможливо).

Варто звернути увагу, що студенту надається велика автономія дій, в саме можливість на самоорганізацію свого часу та логічний розподіл вивчення матеріалу на його власний розсуд. Це є одним 3 перших етапів активації критичного мислення, а саме критичне ставлення то того, чи встигне студент правильно себе організувати та все вивчити без тотального контролю викладача, як це зазвичай відбувається в аудиторії. Інформація про те, як студенти в дистанційному режимі, можуть працювати 3 проектами та над самостійно визначеними проблемами на заняттях $з$ іноземної мови, або ж дослідницькими питаннями та принципами спільної роботи над ними, допомагає вдосконалювати програми навчання, де можливим стає залучення студентів до процесів прийняття рішень. 


\title{
Лiтература:
}

1. Andrade D.F., Tavares H.R, Valle R.C. Teoria da resposta ao Item: Conceitos e Aplicações. Sinape: SINAPE, 2000. 164 p.

2. Drasgow F., Nye C.D., Stark S., Chernyshenko O.S. Differential Item and Test Functioning / ed. Irwing, T. Booth, \& D. J. Hughes. The Wiley Handbook of Psychometric Testing. Manchester, UK: Wiley-Blackwell, 2018. P. 885-899.

3. Safanelli A. D., de Andrade D. F., Schimitt J., Cruz R. M. Evaluation of Ingressants in Distance Education Courses through the Item Response Theory. International Journal of Humanities and Social Science. 2018. № 7. P. 77-86. DOI:10.30845/ijhss.v8n7p.

4. Roberts J. S., Donoghue J. R. A general item response theory for unfolding unidimensional polytomous responses. Applied Psychological Measurement. 2000. № 24. P. 3-32.

DOI https://doi.org/10.30525/978-9934-26-039-1-95

\section{FEEDBACK CLASSIFICATION FOR UNDERGRADUATE TRANSLATORS' TRAINING AND ASSESSMENT}

\author{
Korol T. H. \\ Ph. D. in Pedagogical Studies, Associate professor, \\ Associate professor at the Department of Ukrainian, \\ Foreign Languages and Translation \\ Higher Educational Establishment of Ukoopspilka \\ «Poltava University of Economics and Trade» \\ Poltava, Ukraine
}

Undergraduate translators training in modern Ukrainian universities requires the adoption and application of new approaches to translation performance assessment. In this vein, social constructivist approach to translators' training and assessment seems to be rather promising and influential. Its provisions indicate the need in the arrangement of the efficient collaboration and interaction between the students and teachers in the process of translation performance. Feedback is considered to be part and parcel of such productive communication. In the context of translation training it involves any information delivered by an agent to a student about particular aspects of their translation product or process [3]. Transforming Shute's ideas [5, p. 154] to our research this information should cover the accuracy and 